\title{
Depot-specific release of leptin from subcutaneous and omental adipocytes in suspension culture: effect of tumor necrosis factor- $\alpha$ and transforming growth factor- $\beta 1$
}

\author{
Helga Gottschling-Zeller, Michael Birgel, Dorothee Scriba, Werner F Blum ${ }^{1}$ and Hans Hauner \\ Diabetes Research Institute at the Heinrich-Heine-University Düsseldorf, Clinical Department, D-40225 Düsseldorf, Germany and \\ ${ }^{1}$ Department of Pediatrics, University of Gießen, and Lilly Deutschland GmbH, Bad Homburg, Germany \\ (Correspondence should be addressed to H Hauner, Diabetes Research Institute at the Heinrich-Heine-University Düsseldorf, Auf'm Hennekamp 65, \\ D-40225 Düsseldorf, Germany; Email address: hauner@dfi.uni-duesseldorf.de)
}

\begin{abstract}
Objective: Leptin, the product of the $o b$ gene, is overexpressed in human obesity and increased serum leptin levels are closely correlated with adipose tissue mass, but the regulation of leptin production is not completely understood. The aim of this study was to characterize the role of tumor necrosis factor (TNF)- $\alpha$ and transforming growth factor (TGF)- $\beta 1$ in depot-specific secretion of leptin from cultured human adipocytes.

Design and methods: We measured the leptin concentrations in the culture medium of omental and subcutaneous abdominal adipocytes taken from severely obese individuals and kept in suspension culture, and studied the effect of TNF- $\alpha$ and TGF- $\beta 1$ on leptin release. Leptin protein was measured by radioimmunoassay, leptin mRNA was assessed by reverse transcriptase (RT)-PCR relative to a housekeeping gene.

Results and conclusion: Leptin secretion from subcutaneous fat cells was 2- to 3-fold higher than that from omental fat cells after incubation for 2 and $24 \mathrm{~h}$ respectively. A 2-h exposure of adipocytes to $1 \mathrm{nmol} / \mathrm{l}$ TNF- $\alpha$ and $400 \mathrm{pmol} / \mathrm{l}$ TGF- $\beta 1$ respectively did not significantly affect leptin secretion. Whereas a 24 -h incubation with $1 \mathrm{nmol} / \mathrm{l} \mathrm{TNF}-\alpha$ also did not influence leptin secretion from fat cells from both depots, exposure of omental fat cells to $400 \mathrm{pmol} / \mathrm{l}$ TGF- $\beta 1$ for $24 \mathrm{~h}$ resulted in a significant inhibitory effect (by 33\%) on leptin secretion $(P<0.05)$. A 24- and 48-h exposure of in vitro differentiated human adipocytes to TNF- $\alpha$ led to a significant decrease in leptin mRNA levels to $70 \pm 8 \%$ and $49 \pm 13 \%$ of controls respectively. Similarly, TGF- $\beta 1$ decreased leptin mRNA expression in newly differentiated human adipocytes to $77 \pm 12 \%$ after $24 \mathrm{~h}$ and to $54 \pm 8 \%$ after $48 \mathrm{~h}$ compared with control cultures. These data provide evidence that long-term exposure of human fat cells to TNF- $\alpha$ or TGF- $\beta 1$ may suppress leptin expression in human adipose tissue. The inhibitory effect of TGF- $\beta 1$ appears to be more pronounced in omental as compared with subcutaneous adipocytes.
\end{abstract}

European Journal of Endocrinology 141 436-442

\section{Introduction}

Leptin, the product of the $o b$ gene, is mainly synthesized by adipocytes (1), and is thought to be involved in the central regulation of food intake and energy expenditure $(2-4)$. Recent studies have shown that this protein is overexpressed in human obesity $(5-7)$ and that serum leptin levels are closely correlated with adipose tissue mass $(7,8)$. It has previously been demonstrated that leptin gene expression is higher in the subcutaneous adipose tissue than in the omental fat depots (911). In addition, Van Harmelen et al. recently showed that in women subcutaneous fat tissue pieces secrete more leptin than omental fat tissue pieces (12).
The factors that regulate leptin production are not completely known. Among these, tumor necrosis factor (TNF)- $\alpha$, which is overexpressed in adipose tissue in obesity (13), seems to play a significant role. Grunfeld et al. (14) and Sarraf et al. (15) were the first to report increased leptin gene expression and elevated circulating leptin concentrations in rodents after administration of TNF- $\alpha$.

However, the results of subsequent studies on the direct effects of TNF- $\alpha$ on leptin production in adipocytes gave conflicting results. Kirchgessner et al. (16) and Finck et al. (17) showed that TNF- $\alpha$ can stimulate leptin release from 3T3-L1 adipocytes and primary mouse adipocytes respectively, whereas Yamaguchi et al. (18) demonstrated that a two-day exposure to TNF- $\alpha$ 
inhibits leptin production. Moreover, another study described an inhibition of steady-state ob mRNA levels after treatment of 3T3-L1 adipocytes with proinflammatory cytokines and TNF- $\alpha$ (19).

The latter study also showed that TGF- $\beta$ enhances the level of ob mRNA (19). TGF- $\beta 1$ is a ubiquitously expressed cytokine, which was found to be produced in the adipose tissue of the genetically obese mouse (20). Therefore, it was particularly interesting to study the role of TGF- $\beta 1$ on leptin expression and secretion in human adipose tissue in more detail.

The aim of this study was to compare leptin secretion from subcutaneous and omental adipocytes taken from obese subjects and kept in suspension culture. Furthermore, we examined the possible differential effect of TNF- $\alpha$ and TGF- $\beta 1$ on leptin secretion from subcutaneous and omental adipocytes.

\section{Materials and methods \\ Materials}

Collagenase CLS type 1 was obtained from Worthington (Freehold, NJ, USA); human insulin and cortisol were kindly donated by Hoechst (Frankfurt, Germany); culture media were obtained from Gibco (Berlin, Germany); human transforming growth factor- $\beta 1$ (TGF- $\beta 1$ ) and gentamycin were purchased from Sigma (Munich, Germany) and tumor necrosis factor- $\alpha$ (TNF- $\alpha$ ) from Pepro Tech Inc. (Rocky Hill, NJ, USA); Superscript RT reverse transcriptase, random hexamers, Taq polymerase, PCR buffer, dCTP, dGTC, dTTP and dATP were obtained from Gibco/BRL (Berlin, Germany); $\left[{ }^{33} \mathrm{P}\right] \mathrm{dATP}$ was obtained from Amersham (Braunschweig, Germany); for sequencing we used the ABI PRISM BigDye Terminator Cycle Sequencing Ready Reaction Kit from Perkin Elmer (Weiterstadt, Germany). All other chemicals were from Boehringer (Mannheim, Germany) or Merck (Darmstadt, Germany). Sterile plasticware for tissue culture was purchased from Flow Laboratories (Irvine, UK).

\section{Subjects}

Subcutaneous and omental adipose tissue samples (2 to $10 \mathrm{~g}$ wet weight) were obtained from 14 extremely obese individuals $(8$ females and 6 males, body mass index $(\mathrm{BMI})>40 \mathrm{~kg} / \mathrm{m}^{2}$ ) who underwent vertical gastric banding for weight reduction. Two patients had type 2 diabetes mellitus treated with diet and metformin. Apart from these, the other obese subjects were healthy and did not take any medication. All subjects were of caucasian origin and did not suffer from acute infection, cancer or any other wasting disease. Weight was determined to the nearest $0.5 \mathrm{~kg}$, height to the nearest $\mathrm{cm}$, and BMI was calculated as a measure of the degree of obesity. The clinical characteristics of the patients are summarized in Table 1.
Table 1 Main characteristics of the obese subjects.

\begin{tabular}{lc}
\hline Male/female & $6 / 8$ \\
Age (years) & $38.6 \pm 12.6$ \\
BMI $\left(\mathrm{kg} / \mathrm{m}^{2}\right)$ & $43.9 \pm 8.4$ \\
Subcutaneous fat cell diameter $(\mu \mathrm{m})$ & $124.8 \pm 16.9$ \\
Omental fat cell diameter $(\mu \mathrm{m})$ & $104.5 \pm 16.8$ \\
Subcutaneous fat cell volume $(\mathrm{pl})$ & $1055.4 \pm 436.4$ \\
Omental fat cell volume $(\mathrm{pl})$ & $645.6 \pm 285.4$ \\
\hline
\end{tabular}

\section{Isolation and culture of fat cells}

After removal, the adipose tissue samples were immediately transported to the laboratory in Dulbecco's modified Eagles' medium (DMEM)/Ham's F12 medium containing $4 \%$ bovine serum albumin (BSA). Fat cells were isolated by collagenase digestion according to the method of Rodbell (21). Briefly, the fat specimens were cut into small pieces $\left(1-2 \mathrm{~mm}^{3}\right)$ under sterile conditions and incubated in a collagenase solution $(1.0 \mathrm{mg}$ collagenase perml phosphate-buffered saline (PBS) containing $40 \mathrm{mg} / \mathrm{ml}$ BSA) for approximately $50 \mathrm{~min}$ in a shaking water bath at $37^{\circ} \mathrm{C}$. After enzymatic disaggregation, the floating adipocyte layer was washed three times with PBS buffer supplemented with 4\% BSA. Finally, the undigested tissue was removed by filtration through a nylon mesh of $280 \mu \mathrm{m}$ pore size.

After isolation, fat cell size and fat cell number were determined in small aliquots after defined dilution. The assessment of the mean fat cell diameter of the samples was based on the measurement of at least 150 cells from each adipose tissue sample. The mean fat cell volume was calculated from the diameter and the number of fat cells was determined by dividing the volume of the packed fat cells by the mean fat cell volume.

The freshly isolated fat cells were incubated for the indicated periods of time (usually 24h) in medium consisting of DMEM/F12 supplemented with 4\% BSA, $66 \mathrm{nmol} / \mathrm{l}$ insulin, $100 \mathrm{nmol} / \mathrm{l}$ cortisol and $50 \mu \mathrm{g} / \mathrm{ml}$ gentamycin at $37^{\circ} \mathrm{C}$ in a shaking water bath at a dilution of $1: 10(\mathrm{v} / \mathrm{v})$. The culture medium was then collected and immediately stored at $-80^{\circ} \mathrm{C}$ until later measurement of leptin protein. In separate experiments, TNF- $\alpha$ or TGF- $\beta 1$ was added to the medium at concentrations found to have maximal effects in human adipocytes $(22,23)$.

For assessment of fat cell viability, lactate dehydrogenase $(\mathrm{LDH})$ was assayed in the culture medium at the beginning of the experiment, and after 2, 6, and $24 \mathrm{~h}$ of incubation. There was no significant increase in LDH activity during the 24-h period (data not shown). Furthermore, mean fat cell diameters were determined before and after $24 \mathrm{~h}$ of suspension culture without significant alterations. However, after a 48-h incubation period there was a considerable loss of cells and a reduction in mean fat cell diameter (data not shown). 


\section{In vitro differentiated adipocytes}

The culture model of newly differentiated fat cells was used to study the effects of long-term exposure to TNF- $\alpha$ and TGF- $\beta 1$ on leptin mRNA expression (24). The stromal cell fraction was prepared from subcutaneous adipose tissue samples of young, lean females $(n=8$, mean age $31 \pm 7$ years, BMI $25.8 \pm 2.1 \mathrm{~kg} / \mathrm{m}^{2}$ ) by collagenase digestion as previously described $(21,24)$. Adipose differentiation was obtained under defined serum-free, hormone-supplemented conditions after 16 days in culture with $50-70 \%$ of cells developing the adipocyte phenotype.

\section{RNA extraction and RT-PCR}

Total RNA from cultured cells was prepared according to the method described by Chomczynski and Sacchi (25). After incubation with the respective cytokine for 24 and $48 \mathrm{~h}$ respectively, cells were harvested in Trizol extraction reagent (Life Technologies, Eggenstein, Germany).

The total RNA was dissolved to $0.2 \mu \mathrm{g} / \mu \mathrm{l}$ in Tris/ EDTA buffer, and first strand cDNA was prepared using $5 \mu \mathrm{l}$ RNA, Superscript RT reverse transcriptase, and random hexamers according to the instructions of the manufacturer. cDNA was diluted $1: 8$ with $\mathrm{H}_{2} \mathrm{O}$ and PCR was carried out using $7 \mu \mathrm{l}$ diluted cDNA and a PCR primer mix containing $1.0 \mathrm{U}$ Taq polymerase in its $1 \times$ buffer, $40 \mu \mathrm{mol} / \mathrm{l}$ each of dCTP, dGTP, dTTP, $20 \mu \mathrm{mol} / \mathrm{l}$ dATP, $2.5 \mu \mathrm{Ci} 1000-3000 \mathrm{Ci} / \mathrm{mmol}$ [alpha- ${ }^{33} \mathrm{P}$ ]dATP, and $10 \mathrm{pmol}$ of each primer in a $50 \mu \mathrm{l}$ volume with 50 $\mu \mathrm{l}$ mineral oil. PCR conditions were a denaturation step at $95^{\circ} \mathrm{C}$ for $1 \mathrm{~min}$ followed by 26 cycles of $94^{\circ} \mathrm{C}, 30 \mathrm{~s}$; $57^{\circ} \mathrm{C}, 30 \mathrm{~s} ; 72^{\circ} \mathrm{C}, 30 \mathrm{~s}$. PCR products were analyzed on a $6 \%$ polyacrylamide $/ 7 \mathrm{~mol} / \mathrm{l}$ urea gel exposed to a Phospho-Imager screen suitable for quantification as described recently (9). In this semi-quantitative RT-PCR the following two primer sets were used simultaneously in the same tube: human leptin gene specific primers: 5'-primer, 5'- GACTTCATTCCTGGGCTCCAC-3', 3'primer, 5'-CCTGAAGCTTCCAGGACACC- $3^{\prime}$ and as internal standard specific primers for the transcription factor Sp1: 5'-primer, 5'-GAGAGTGGCTCACAGCCTGTC-3', 3' primer, 5'-GTTCAGAGCATCAGACCCCTG-3'. The PCR reaction was also performed in the absence of reverse transcriptase to exclude contamination by genomic DNA. The sequence of the leptin transcript was confirmed using the ABI PRISM BigDye Terminator Cycle Sequencing Ready Reaction Kit according to the instructions of the manufacturer.

\section{Measurement of leptin concentration in the culture medium}

Leptin was measured in the conditioned medium at 2, 6 and $24 \mathrm{~h}$ respectively, using a specific highly sensitive radioimmunoassay (RIA) as described recently (26).

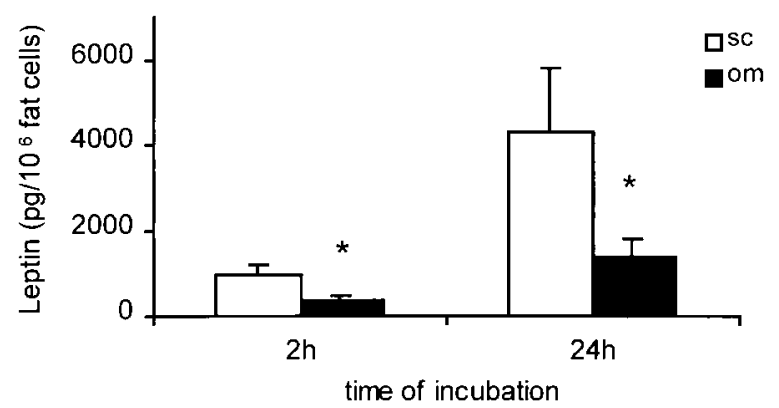

Figure 1 Comparison of leptin release into the culture medium between subcutaneous (sc) and omental (om) human adipocytes from 14 obese subjects after incubation for 2 and $24 \mathrm{~h}$ respectively. Data represent mean values \pm S.E.M. of leptin concentrations in the culture medium. ${ }^{\star} P<0.01$ (non-parametric Wilcoxon test).

The intra- and interassay coefficients of variation were $0.8 \%$ and $8.5 \%$ respectively.

\section{Statistical analysis}

Results are expressed as means \pm s.E.M. Differences between groups were tested using the non-parametric Wilcoxon test. Differences with a $P$ value $<0.05$ were regarded as significant.

\section{Results}

\section{Secretion of leptin from subcutaneous and omental adipocytes in suspension culture}

To compare leptin production between the two adipose tissue depots under investigation, we used isolated subcutaneous and omental fat cells from the same subject under identical conditions. In the total group of 14 subjects, the leptin concentration in the culture medium of subcutaneous fat cells was 2.5-fold higher than in the medium of omental fat cells after 2-h incubation (subcutaneous adipocytes: 974.6 $\pm 211.1 \mathrm{pg} /$ $10^{6}$ fat cells, omental adipocytes: $386.5 \pm 110.5 \mathrm{pg} /$ $10^{6}$ fat cells, $P<0.05$ ) and 3 -fold higher after 24 -h incubation respectively (subcutaneous adipocytes: $4325.5 \pm 1492.4 \mathrm{pg} / 10^{6}$ fat cells, omental adipocytes: $1400.3 \pm 396.4 \mathrm{pg} / 10^{6}$ fat cells, $P<0.05$ ) (Fig. 1). The leptin concentration in the culture medium, although varying from donor to donor, increased linearly in a time-dependent manner in both subcutaneous and omental adipocytes (data not shown).

When leptin secretion was expressed per fat cell volume this regional difference became smaller, but remained significant (data not shown). Furthermore, there was a positive correlation between leptin secretion from subcutaneous adipocytes and fat cell volume $(r=0.18 ; P \leq 0.05)$.

Further analysis of the data revealed a gender difference. The amount of leptin released into the culture medium after 2-h incubation from subcutaneous 


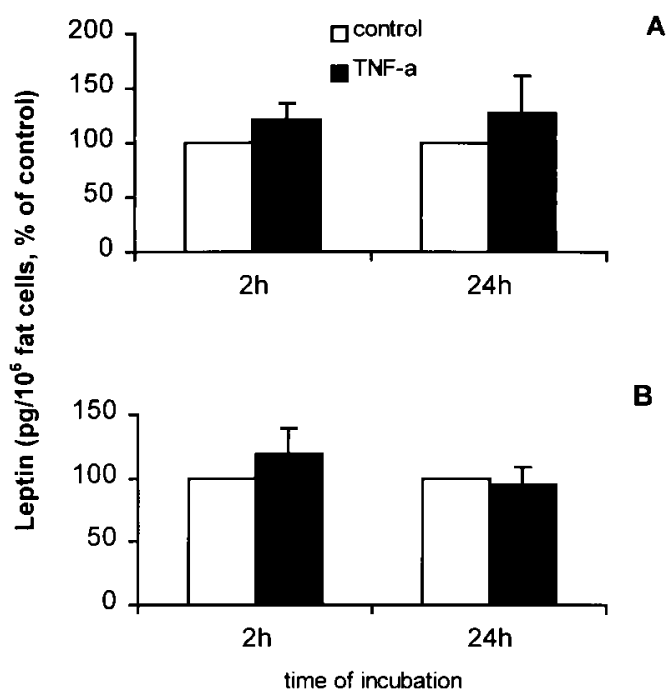

Figure 2 Effect of $1 \mathrm{nmol} / \mathrm{ITNF}-\alpha$ on leptin secretion from human adipocytes after 2 and $24 \mathrm{~h}$ of exposure respectively, in comparison with control cultures. (A) Subcutaneous adipocytes. (B) Omental adipocytes. Data represent means \pm S.E.M. of leptin concentrations in the medium from 10 and 8 separate experiments with subcutaneous adipocytes exposed for 2 and $24 \mathrm{~h}$ respectively, and from 9 and 6 separate experiments with omental adipocytes exposed for 2 and $24 \mathrm{~h}$ respectively.

adipocytes of female subjects was 2-fold higher than from subcutaneous adipocytes obtained from male subjects at comparable fat cell size (subcutaneous adipocytes from females: $1034.2 \pm 236.5 \mathrm{pg} / 10^{6}$ fat cells; subcutaneous adipocytes from male subjects: $468.3 \pm 182.7 \mathrm{pg} / 10^{6}$ fat cells) (not significant (NS)), whereas no significant gender difference in leptin release was seen for omental adipocytes (data not shown).

\section{Effect of TNF- $\alpha$ on leptin secretion}

As the results of previous studies on the effect of TNF- $\alpha$ on leptin production in adipocytes from different origin were contradictory $(14,15,17-19)$, we examined the role of TNF- $\alpha$ on leptin production in cultured human adipocytes. Isolated fat cells from the two depots were incubated with $1 \mathrm{nmol} / \mathrm{l} \mathrm{TNF}-\alpha$. After a 2-h incubation a slight, but statistically not significant increase in leptin was observed both in subcutaneous (leptin concentration increased by $21 \pm 15 \%$, NS, $n=10$ ) and omental (leptin concentration increased by $19 \pm 20 \%$, NS, $n=9$ ) fat cells in comparison with cells cultured without TNF- $\alpha$ (Fig. 2). After $24 \mathrm{~h}$, the leptin concentration in the culture medium was increased by $28 \pm 34 \%$ (NS, $n=8)$ in subcutaneous fat cells and decreased by $5 \pm$ $14 \%$ (NS, $n=6)$ in omental fat cells compared with controls (Fig. 2).

Because of the temporal limitations of the suspension culture system, we used, additionally, the model of in vitro differentiated human adipocytes $(24,26)$ to examine the effect of TNF- $\alpha$ on leptin mRNA expression.

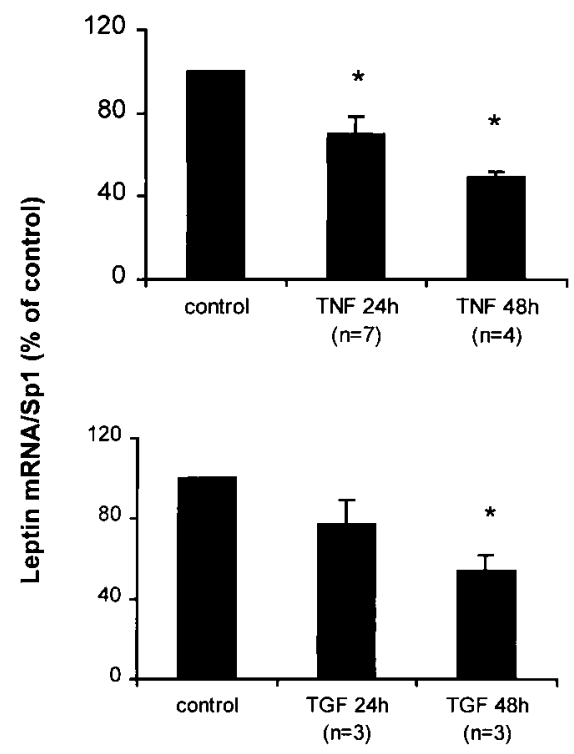

Figure 3 Effect of a 24- and 48-h exposure of in vitro differentiated human fat cells to $1 \mathrm{nmol} / \mathrm{INF}-\alpha$ and to $400 \mathrm{pmol} / \mathrm{ITF}-\beta 1$ respectively, on leptin mRNA levels compared with control cultures. Data represent mean values \pm S.E.M. ${ }^{*} P<0.05$.

A 24-h incubation of newly differentiated adipocytes with $1 \mathrm{nmol} / \mathrm{l}$ TNF- $\alpha$ significantly decreased leptin mRNA levels to $70 \pm 8 \%$ of controls $(P<0.05, n=7)$ (Fig. 3). The decrease in leptin mRNA levels was even greater after a 48 -h exposure to $1 \mathrm{nmol} / \mathrm{l} \mathrm{TNF}-\alpha$ (to 49 $\pm 13 \%, P<0.05, n=4$ ) (Fig. 3), indicating a timedependent decrease in leptin mRNA expression in response to TNF- $\alpha$ exposure.

\section{Effect of TGF- $\beta 1$ on leptin secretion}

As TGF- $\beta$ was recently reported to be overexpressed in adipose tissue from obese mice (20) and to have potent antiadipogenic properties in human adipose tissue (23), we studied the possible role of this cytokine on the regulation of leptin secretion in cultured human adipocytes. When $400 \mathrm{pmol} / \mathrm{l}$ TGF- $\beta 1$ was present in the culture medium for $2 \mathrm{~h}$, leptin release into the culture medium remained unchanged, both in subcutaneous $(100 \pm 9 \%, \mathrm{NS}, n=11)$ and omental (91 \pm $14 \%$, NS, $n=8$ ) fat cells compared with controls (Fig. 4). After $24 \mathrm{~h}$, the leptin concentration was reduced to 86 $\pm 9 \%(\mathrm{NS}, n=8)$ in the medium of subcutaneous fat cells and to $67 \pm 11 \%(P \leq 0.05 ; n=6)$ in the medium of cultured omental cells compared with controls (Fig. 4).

To investigate the effect of TGF- $\beta 1$ on steady-state leptin mRNA levels we again used the model of in vitro differentiated adipocytes. Exposure of cells to $400 \mathrm{pmol} / \mathrm{l}$ TGF- $\beta 1$ appeared to inhibit leptin mRNA expression in a time-dependent manner (Fig. 4). After 24- and 48-h incubation with TGF- $\beta 1$, leptin mRNA levels were decreased to $77 \pm 12 \%(\mathrm{NS}, n=3)$ and to $54 \pm 8 \%$ $(P<0.05 ; n=3)$ of control cultures respectively (Fig. 3$)$. 


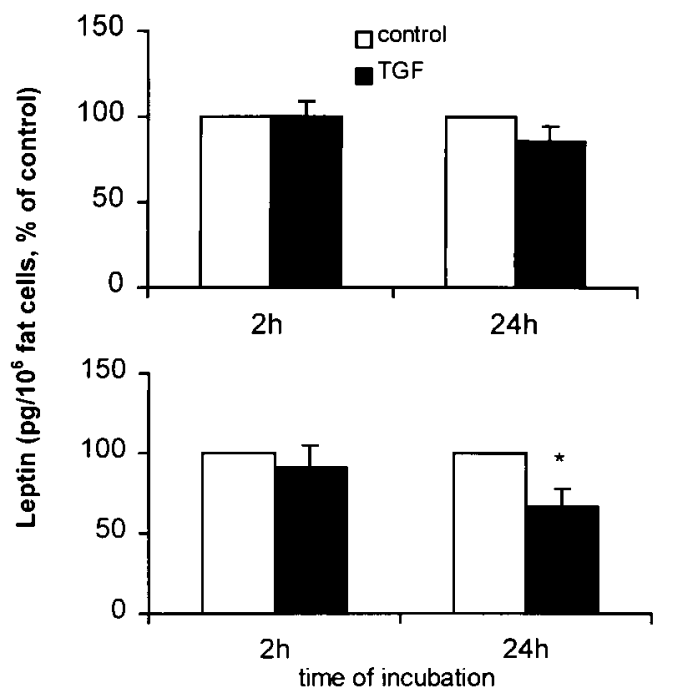

Figure 4 Effect of $400 \mathrm{pmol} / \mathrm{l}$ TGF- $\beta 1$ on leptin secretion from isolated human adipocytes after a 2- and 24-h incubation period respectively. (A) Subcutaneous adipocytes. (B) Omental adipocytes. Data represent mean values \pm S.E.M. of leptin concentrations in the culture medium from 11 and 8 separate experiments with subcutaneous fat cells exposed for 2 and $24 \mathrm{~h}$ respectively, and from 8 and 6 separate experiments with omental fat cells exposed for 2 and $24 \mathrm{~h}$ respectively. ${ }^{\star} P<0.05$ (non-parametric Wilcoxon test).

\section{Discussion}

In this study, we compared leptin secretion from isolated subcutaneous and omental human adipocytes from extremely obese subjects maintained in suspension culture. We first characterized this model and found a time-dependent increase in leptin concentrations in the culture medium for up to $24 \mathrm{~h}$.

The results of our experiments clearly demonstrate that subcutaneous adipocytes from extremely obese subjects release significantly more leptin than omental adipocytes. This finding is in agreement with the data of Van Harmelen et al., who recently showed greater leptin secretion in subcutaneous than in omental adipose tissue in an in vitro model of adipose tissue fragments from obese and non-obese women (12). However, tissue fragments contain many other cell types which could affect leptin production. Therefore, our data strongly indicate that this depot-specific difference may be an inherent characteristic of the adipocytes from both regions. Previous studies from several groups including ours (9-11) have provided the first evidence for a regional difference in leptin expression, as they demonstrated higher leptin mRNA levels in subcutaneous than in omental adipose tissue samples from obese and nonobese subjects.

The regional difference in leptin secretion may be partly due to the difference in mean fat cell volume, as subcutaneous fat cells were on average larger than omental fat cells and as a positive correlation was found between fat cell volume and leptin secretion from subcutaneous adipocytes. However, after adjustment for cell volume, the regional difference remained significant.

Our data also showed a gender-related difference in leptin release, but only in the subcutaneous fat cells. Previous studies have established that both mRNA levels and serum concentrations of leptin are higher in women than in men (6-8). As we recently found that testosterone suppresses leptin production (27), this gender difference in leptin expression is probably due to differences in sex steroid concentrations and action. Why this gender difference was not detectable in omental fat cells is unclear and requires further investigation.

Another purpose of this study was to examine the effect of two cytokines on leptin expression and secretion in adipose tissue. Like leptin, TNF- $\alpha$ is known to be overexpressed in human obesity (28-30). Previous short-term in vivo studies showed a stimulatory effect of TNF- $\alpha$ on leptin gene expression and serum leptin concentrations in rodents after administration of TNF- $\alpha(14,15)$. In addition, it has recently been reported that infusion of TNF- $\alpha$ over 5 days in humans with solid tumors increases serum leptin levels $12 \mathrm{~h}$ after application with subsequent return to baseline levels within $24 \mathrm{~h}$ (31). Kirchgessner et al. described a rapid stimulation of leptin release by this cytokine in 3T3-L1 adipocytes with a maximum effect at $6 \mathrm{~h}$, leading to the conclusion that TNF- $\alpha$ can act directly on adipocytes to regulate the release of leptin from a preformed pool (16). Finck et al. also reported an increased secretion of leptin after a 24-h stimulation by TNF- $\alpha$ in an in vitro model of primary mouse adipocytes (17). In the human model, we found a rapid but rather modest increase in the secretion of leptin from omental and subcutaneous fat cells after a 2-h exposure to TNF- $\alpha$, supporting speculation on a possibly small leptin pool in man. However, there is otherwise little evidence as yet that leptin is stored in the adipocyte and rapidly released upon defined stimuli. After a 24-h incubation, we still detected a rather small positive effect of TNF- $\alpha$ on leptin release into the culture medium, but only in cultured subcutaneous adipocytes.

Very recent studies investigated the effect of a longer exposure of fat cells to TNF- $\alpha$. In the study published by Yamaguchi et al. (18), a 4-day exposure of isolated human subcutaneous adipocytes to $100 \mathrm{ng} / \mathrm{ml}$ TNF- $\alpha$ led to an inhibition of leptin secretion. Another group reported a decrease in ob mRNA in 3T3-L1 cells after treatment with $200 \mathrm{ng} / \mathrm{ml} \mathrm{TNF-} \alpha$ for $24 \mathrm{~h}$ (19). This finding is in agreement with the data of Kirchgessner et al. (16) who demonstrated a rapid time-dependent decline in leptin mRNA during TNF- $\alpha$ treatment, possibly due to RNA destabilization as speculated by the authors. Our data showed a significant decrease in leptin mRNA levels after a 24-h exposure to TNF- $\alpha$ with a more pronounced reduction after a 48 -h period. Thus, our results and those from the literature may support 
the view that TNF- $\alpha$ is able acutely to promote leptin secretion from isolated human adipocytes, but at least longer exposure of adipocytes to TNF- $\alpha$ appears to result in a suppression of leptin production. It is unclear whether and to what degree this rapid mobilization of leptin may be involved in the anorectic action exerted by TNF- $\alpha$.

Little is known about the effect of the multifunctional cytokine TGF- $\beta 1$ on leptin release from subcutaneous and omental fat cells, although a recent study suggested that TGF- $\beta 1$ is overexpressed in adipose tissue from genetically obese mice (20). To date, there is only one study that indicates a potential capacity of TGF- $\beta 1$ to modulate leptin mRNA expression. In 3T3-L1 adipocytes, a 4-h exposure to TGF- $\beta 1$ increased the level of ob mRNA in a concentration-dependent fashion. This effect was no longer evident after a 24-h incubation (19). In contrast, we were unable to find an acute stimulatory effect of TGF- $\beta 1$ on leptin release into the culture medium of fat cells from both adipose tissue depots. After a 24-h incubation, we observed a tendency for decreased leptin secretion from subcutaneous adipocytes and a significant reduction in leptin release from omental adipocytes. Our data also indicate a reduction in leptin mRNA expression after a 24- and 48 -h incubation with TGF- $\beta 1$. It is currently unknown whether TGF- $\beta 1$ is overexpressed in human obesity. If this should be the case, it may become an important question whether TGF- $\beta 1$ contributes to the regulation of leptin production in human adipose tissue. Although still unproven, it is tempting to speculate that TGF- $\beta 1$, similar to TNF- $\alpha$, may act by autocrine and/or paracrine mechanisms on leptin production. It is noteworthy in this context that both cytokines exert to some extent similar antiadipogenic and catabolic actions on human adipocytes in primary culture. Both cytokines have been found to reduce the activity of lipogenic enzymes in human adipocytes and to strongly prevent adipose differentiation (22, 23).

In conclusion, our experiments on the depot-specific regulation of leptin production and release, particularly the regulation by cytokines, suggest that long-term exposure of human fat cells to both TNF- $\alpha$ and TGF- $\beta 1$ may result in suppression of leptin production in both subcutaneous and omental adipocytes from extremely obese subjects. In addition, the data provide weak evidence that TNF- $\alpha$ is able to rapidly mobilize leptin from adipocytes, possibly by a posttranslational mechanism.

\section{Acknowledgements}

We wish to thank Prof. B Husemann and his team from the Surgical Department, Dominikus-Krankenhaus, Düsseldorf-Heerdt, for their support in obtaining adipose tissue samples from obese patients.

\section{References}

1 Zhang Y, Proenca R, Maffei M, Barone M, Leopold L \& Friedman JM. Positional cloning of the mouse obese gene and its human homologue. Nature 1994372 425-432.

2 Campfield LA, Smith FJ, Guisez Y, Devos R \& Burn P. Recombinant mouse OB protein: evidence for a peripheral signal linking adiposity and central neural networks. Science $1995269546-$ 549 .

3 Halaas JL, Gajiwala KS, Maffei M, Cohen SL, Chait BT, Rabinowitz $\mathrm{D}$ et al. Weight-reducing effects of the plasma protein encoded by the obese gene. Science 1995269 543-546.

4 Pelleymounter MA, Cullen MJ, Baker MB, Hecht R, Winters D, Boone $\mathrm{T}$ et al. Effect of the obese gene product on body weight regulation in $o b / o b$ mice. Science $1995269546-549$.

5 Hamilton BS, Paglia D, Kwan AYM \& Deitel M. Increased obese mRNA expression in omental fat cells from massively obese humans. Nature Medicine 19951 953-956.

6 Lönnqvist F, Arner P, Nordfors L \& Schalling M. Overexpression of the obese $(o b)$ gene in adipose tissue of human obese subjects. Nature Medicine 19951 950-953.

7 Maffei M, Halaas J, Ravussin E, Pratley RE, Lee GH, Zhang Yet al. Leptin levels in human and rodents: measurement of plasma leptin and ob mRNA in obese and weight-reduced subjects. Nature Medicine 19951 1155-1161.

8 Considine RV, Sinha MK, Heimen ML, Kriauciunas A, Stephens TW, Nyce MR et al. Serum immunoreactive-leptin concentrations in normal-weight and obese humans. New England Journal of Medicine $1996334292-295$.

9 Hube F, Lietz U, Igel M, Jensen PB, Tornqvist H, Joost H-G et al. Difference in leptin mRNA levels between omental and subcutaneous abdominal adipose tissue from obese humans. Hormone and Metabolic Research 199628 690-693.

10 Masuzaki H, Ogawa Y, Isse N, Satoh N, Okazaki T, Shigemoto M et al. Human obese gene expression. Adipocyte-specific expression and regional differences in the adipose tissue. Diabetes 199544 855-858.

11 Montague CT, Prins JB, Sanders L, Digby JE \& O'Rahilly S. Depotand sex-specific differences in human leptin mRNA expression. Implications for the control of regional fat distribution. Diabetes $199746342-347$.

12 Van Harmelen V, Reynisdottir S, Eriksson P, Thörne A, Hoffstedt J, Lönnqvist $\mathrm{F}$ et al. Leptin secretion from subcutaneous and visceral adipose tissue in women. Diabetes 199847 913-917.

13 Hotamisligil GS, Shargill NS \& Spiegelman BM. Adipose expression of tumor necrosis factor-alpha: direct role in obesity-linked insulin resistance. Science 1993259 87-91.

14 Grunfeld C, Zhao C, Fuller J, Pollack A, Moser A, Friedman J et al. Endotoxin and cytokines induce expression of leptin, the ob gene product, in hamsters. Journal of Clinical Investigation 199697 2152-2157.

15 Sarraf P, Frederich RC, Turner EM, Ma G, Jaskowiak NT, Rivet DJ, 3rd et al. Multiple cytokines and acute inflammation raise mouse leptin levels: potential role in inflammatory anorexia. Journal of Experimental Medicine 1997185 171-175.

16 Kirchgessner TG, Uysal KT, Wiesbrock SM, Marino MW \& Hotamisligil GS. Tumor necrosis factor-alpha contributes to obesity-related hyperleptinemia by regulating leptin release from adipocytes. Journal of Clinical Investigation $19971002777-2781$.

17 Finck BN, Kelley KW, Dantzer R \& Johnson RW. In vivo and in vitro evidence for the involvement of tumor necrosis factor-alpha in the induction of leptin by lipopolysaccharide. Endocrinology 1998 $1392278-2283$.

18 Yamaguchi M, Murakami T, Tomimatsu T, Nishio Y, Mitsuda N, Kanzaki $\mathrm{T}$ et al. Autocrine inhibition of leptin production by tumor necrosis factor-alpha (TNF-alpha) through TNF-alpha type-I receptor in vitro. Biochemical and Biophysical Research Communications 1998244 30-34.

19 Granowitz EV. Transforming growth factor- $\beta$ enhances and proinflammatory cytokines inhibit OB gene expression in 3T3-L1 
adipocytes. Biochemical and Biophysical Research Communications $1997240382-385$.

20 Samad F, Yamamoto K, Pandey M \& Loskutoff DJ. Elevated expression of transforming growth factor- $\beta$ in adipose tissue from obese mice. Molecular Medicine 19973 37-48.

21 Rodbell M. Metabolism of isolated fat cell. I. Effects of hormones on glucose metabolism and lipolysis. Journal of Biological Chemistry 1964239 375-380.

22 Petruschke T \& Hauner H. Tumor necrosis factor- $\alpha$ prevents the differentiation of human adipocyte precursor cells and causes delipidation of newly developed fat cells. Journal of Clinical Endocrinology and Metabolism 199376 742-747.

23 Petruschke T, Röhrig K \& Hauner H. Transforming growth factor beta (TGF- $\beta$ ) inhibits the differentiation of human adipocyte precursor cells in primary culture. International Journal of Obesity $199418532-536$.

24 Hauner H, Entenmann G, Wabitsch M, Gaillard D, Ailhaud G, Negrel $\mathrm{R}$ et al. Promoting effects of glucocorticoids on the differentiation of human adipocyte precursor cells cultured in a chemically defined medium. Journal of Clinical Investigation 1989 84 1663-1670.

25 Chomczynski P \& Sacchi N. Single-step method of RNA isolation by acid guanidinium thiocyanate-phenol-chloroform extraction. Analytical Biochemistry 1987162 156-159.

26 Wabitsch M, Jensen PB, Blum WF, Christoffersen CT, Englaro P, Heinze E et al. Insulin and cortisol promote leptin production in cultured human fat cells. Diabetes 199645 1435-1438.
27 Wabitsch M, Blum WF, Muche R, Braun M, Hube F, Rascher W et al. The contribution of androgens to the gender difference in leptin production on obese children and adolescents. Journal of Clinical Investigation 1997100 808-813.

28 Hotamisligil GS, Arner P, Caro JF, Atkinson RL \& Spiegelman BM. Increased adipose tissue expression of tumor necrosis factor- $\alpha$ in human obesity and insulin resistance. Journal of Clinical Investigation 199595 2409-2415.

29 Kern PA, Saghizadeh M, Ong JM, Bosch RJ, Deem R \& Simsolo RB. The expression of tumor necrosis factor in human adipose tissue. Regulation by obesity, weight loss, and relationship to lipoprotein lipase. Journal of Clinical Investigation 1995952111 2119.

30 Hube F, Birgel M, Lee Y-M \& Hauner H. Expression pattern of tumour necrosis factor receptors in subcutaneous and omental human adipose tissue: role of obesity and non-insulin-dependent diabetes mellitus. European Journal of Clinical Investigation 199929 (In Press).

31 Zumbach MS, Boehme MWJ, Wahl P, Stremmel W, Ziegler R \& Nawroth PP. Tumor necrosis factor increases serum leptin levels in humans. Journal of Clinical Endocrinology and Metabolism 1997 82 4080-4082.

Received 24 March 1999

Accepted 24 June 1999 